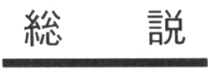

\title{
母乳打よび調製粉乳と乳児の脂質栄養
}

\author{
米久保 明得 \\ 明治乳業株式会社栄養科学研究所 \\ （１89-8530＼cjkstart東京都東村山市栄町 1-21-3）
}

\section{Breast Milk and Infant Formula and Infant Lipid Nutrition}

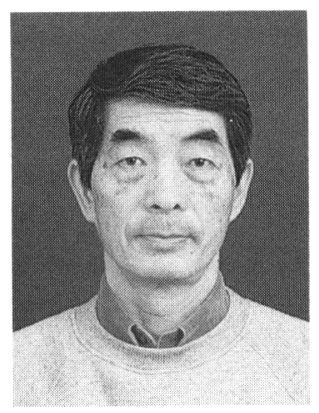

\author{
Akie Yonekubo \\ Nutrition Science Institute Meiji Milk Products, Co. Ltd. \\ (1-21-3, Sakae, Higashimurayama-shi, Tokyo 189-8530)
}

\begin{abstract}
Breast milk is the best source of nutrition for infant growth and development. Breast feeding an infant is not always possible because have insufficient in quantity of breast milk or social conditions. In such a case, infant formula sufficient for growth and development must be used. Large amounts of polyunsaturated fatty acids (PUFA), i.e., linoleic acid, arachidonic acid, alfa-liolenic acid, eicosapentaenoic acid and docosahexaenoic acid (DHA) are present in breast milk. Infant formula well-balanced in essential fatty acids was produced subsequent to demonstrating the need for alfa-liolenic acid.

DHA-fortified infant formula was recently been developed to provide DHA equivalent to that in Japanese human milk, because DHA is essential to development of the neonatal brain and retina. Visual acuity and/or visual evoked potential assessed the significance of PUFA for term infants. The results were compared with the learning ability of rats.
\end{abstract}

Key words : human milk, visual acuity, learning ability, term infants

\section{1 はじめに}

出生後から 1 藏までの乳児期は成人と異なり，種々の 器官が発達をする大変重要な時期である。特に脳など神 経に倸わる器官の発達に重要な時期に当たる。同時にま た生体内に打ける必要栄養成分を合成する能力が弱い時 期でもある。したがって，乳児に対しての栄養補給を考 えたとき，出産前の母体からの胎盤経由による胎児への 栄養成分等の補給と出産後の乳児に対する母乳からの栄 養成分の補給が実際に重要な点である。栄養成分の中で も母乳に含まれていて, 乳児の脳や目の網膜の発達に重 要な役割を果たす ${ }^{11 〜 5)}$ といわ扎ている $\mathrm{n}-3$ 系高度不飽和 脂肪酸の一つであるドコサへキサエン酸（Docosahexaenoic acid：DHA）に注目して，DHAの乳幼児期におけ る生理的役割につき述べたい。また, 母親の母乳分泌量 が不足気味であったり, 社会的環境や医学的な面から母 乳が与えられないような場合には，母乳に代わりうる唯 一の食品として乳児用調製粉乳が存在する。したがって, 母乳打よび母乳の代替となる調製粉乳の組成とその生理
的役割，および調製粉乳の果たすべき役割につき，最近 の報告を中心にとりまとめてみた。

DHA の生体内合成能力は正常に出産した成熟児でさ えも弱いといわれ，生後の正常な発達にとって DHA の 食事からの掑取㳄加せなことが常識的になってきた 現在, 妊娠 40 週齢未満で出産した早産児のような場合 には，大きなリスクを抱えて出産してきたことになる。 DHA 等の生体に必要な栄養成分は, 奸娠後半の 3 力月 の間（Third trimester）に母親から供給され，胎児に吸 収される。この重要な時期に入る前に出産してしまった 場合, DHAの生体内蓄積量が少ない状態で生まれてく るので, 食事から DHA 等の不飽和脂肪酸を摂取しなけ れば乳罗の正常な神経発達がますます期待できない。こ れまで, 早産児における DHA 等の不飽和脂肪酸の必要 性に関する報告が多く発表されてきた。早産児に打ける DHAの必要性は確かなものになったとい方る。しかし， 成熟児に抢ける DHAの必要性はあるか否かがこれから の話題となっており, 成熟児における高度不飽和脂肪酸 の必要性に関する研究報告が次第に多くなってきた状況 
にある。成熟児の報告例をもとに，DHAの必要性を考 えてみた。

\section{2 母乳の脂肪酸組成}

乳児栄養を考える際に重要なことは，乳児にとっての 最適な栄養源である母乳の組成である。母乳の組成は一 般に母親の食事によって影響され，特に脂肪酸組成，お よび脂溶性ビタミンや水溶性ビタミンの含量が食事中の これらの栄養成分レべルによって影響される。一方, 出 生した乳児の最適な食事は母乳であることはいうまでも ないことであるが，ときには母乳の出方が悪くて不足を きたしたり，母親の健康状態などによって母乳を与えら れないことが生じる。そのとき母乳に代わり得る唯一の 安全に与えられる食品は乳児用調製粉乳 (調粉) である。 この調粉の品質設計を行うに当たって母乳のよい点を調 粉に生かすことは大切であり，同時に乳児栄養を考虑す る中で母乳の組成，特に脂肪酸組成を知ることは大変重 要である。この意味で，世界各国それぞれの国の母乳中 の脂肪酸組成が測定され，報告されている。そこで，日 本人の母乳の脂肪酸組成分析結果を世界各国の母乳中の 脂肪酸組成と比較して Table 1 に示した。母乳中には多 種類の不飽和脂肪酸が含まれており， $\mathrm{n}-6$ 系不飽和脂肪 酸であるリノール酸やその代謝産物であるアラキドン 酸， $\mathrm{n}-3$ 系不飽和脂肪酸である $\alpha-$ リノレン酸およびそ の代謝産物であるDHA などが存在する。最近のデータ では，日本人母乳中のリノール酸含量が高くなり，米国 のデータに近い值であった。これは，日本人の食生活が
欧米化したことにより脂肪の掑取量が増加し，それに 伴ってリノール酸の掑取量も増大し, 乳汁中にその分多 くリノール酸が分泌された結果と考えられた。一方, $\alpha^{-1}$ リノレ酸のレベルは他の国の母乳に比べて高目で あった。DHA レベルは日本人母乳の場合，0.63〜1.0\% であり, 他の国のデータに比べて約 2 3 倍高い值が得 られている。前述の通り, 日本人母乳中に比較的多くの DHA が含まれているのは，月本人が DHAを含む魚を 常食する民族のため，摂取した DHA が母乳中に分泌さ れたものと考えられる。また，魚を特に多く椇取してい るわけでもない欧米諸国の母乳中にも多少 DHA が羿め られることを勘案すると，时乳の合目性から見てこのレ ベルは, DHAの最低必要量を示しているとも考元られ る。

母乳といっても国により，また時代によって食生活が 変化すると母乳組成も変化しうる。欧米の母乳に比べて, 日本人母乳中には $\alpha$-リノレン酸やDHAのような $\mathrm{n}-3$ 系不飽和脂肪酸が比較的多く含まれていることはすでに 分かっている。日本人は, 前述の通り, 欧米人に比べて $\alpha$ リノレン酸を比較的多く含む大豆製品や DHA の供給 源となる魚を多く搷取するからであると考えられる。 DHA は，乳児の脳や網膜に多く含まれている。乳児期， 特に新生児期には不飽和化酵素活性が弱いことから，生 体内での $\alpha$-リノレン酸からの代謝産物であるDHAの 合成量が少なく, DHAの体内蓄積量が少なくなりがち になる。特に早産児など未熟な場合にはなおさらである。 母乳中にDHA が含まれるのは, 新生児期の脳や網膜等

Table 1 Comparison of Polyunsaturated Fatty Acids (PUFA) in the Human Milk ${ }^{6}$.

\begin{tabular}{|c|c|c|c|c|c|}
\hline $\begin{array}{l}\text { Reporters } \\
\text { Lactation Periods }\end{array}$ & $\begin{array}{l}\text { Yonekubo et al } \\
21 \mathrm{~d}-2 \mathrm{M}\end{array}$ & $\begin{array}{c}\text { Idota et al } \\
31-60 \mathrm{~d}\end{array}$ & $\begin{array}{c}\text { Gibson et al } \\
40-45 \mathrm{~d}\end{array}$ & $\begin{array}{l}\text { Bitman et al } \\
37-40 \text { weeks }\end{array}$ & $\begin{array}{c}\text { Koletzko et al } \\
3-4 \mathrm{M}\end{array}$ \\
\hline Countries & Japan & Japan & Australia & USA & Germany \\
\hline Survey year & 1980 & 1989 & 1981 & 1983 & 1988 \\
\hline Number & 735 & 562 & 61 & 6 & 15 \\
\hline \multicolumn{6}{|l|}{ n-6PUFA } \\
\hline Linoleic acid & 14.68 & 13.96 & 10.75 & 15.58 & 10.76 \\
\hline$\gamma$-Linolenic acid & & 0.11 & 0.35 & & 0.16 \\
\hline Eicosadienoic acid & 0.30 & 0.33 & 0.24 & 0.18 & 0.34 \\
\hline Dihomo- $\gamma$-Linolenic acid & 0.23 & 0.32 & 0.31 & 0.53 & 0.06 \\
\hline Arachidonic acid & 0.28 & 0.40 & 0.40 & 0.60 & 0.36 \\
\hline Docosatetraenoic acid & & 0.08 & 0.10 & 0.07 & 0.08 \\
\hline Total & 15.49 & 15.20 & 12.15 & 16.39 & 12.26 \\
\hline \multicolumn{6}{|l|}{ n-3PUFA } \\
\hline$\alpha$-Linolenic acid & 1.59 & 1.53 & 0.59 & 1.03 & 0.81 \\
\hline EPA & 0.12 & 0.24 & 0.16 & 0.00 & 0.04 \\
\hline Docosapentaenoic acid & 0.15 & 0.30 & 0.21 & 0.11 & 0.17 \\
\hline DHA & 0.63 & 1.00 & 0.32 & 0.23 & 0.22 \\
\hline Total & 2.49 & 3.26 & 1.28 & 1.37 & 1.38 \\
\hline$n-6 / n-3$ & 6.22 & 4.26 & 9.49 & 11.96 & 9.23 \\
\hline
\end{tabular}




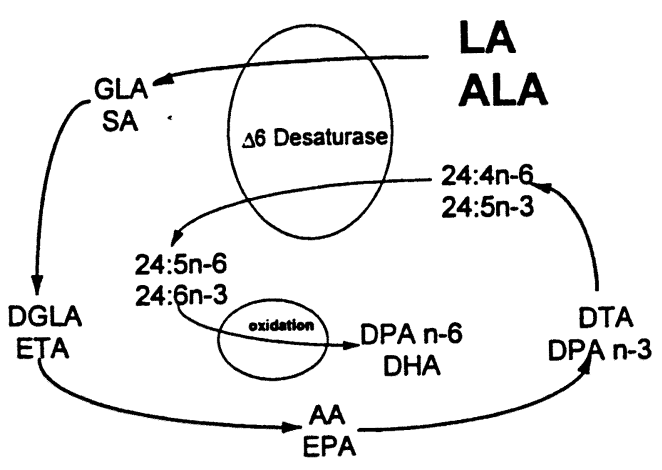

Fig. 1 Metabolism of Fatty Acids ${ }^{15}$. Abbreviations :

LA : Linoleic acid, ALA : $\alpha$-Linolenic acid, GLA : $\gamma$-Linolenic acid, SA : Stearidonic acid (18: $4 \mathrm{n}$-3), DGLA : Dihome- $\gamma$-linolenic acid, ETA : Eicosatetraenoic acid, AA : Arachidonic acid, EPA : Eicosapentaenoic acid, DTA : Docosatetraenoic acid, DPA n-3 : Docosapentaenoic acid n-3, DPA n-6 : Docosapentaenoic acid n-6, DHA : Docosahexaenoic acid.

組織の発有, 発達に必要な DHA を母乳から椇取できる ように配虑された母乳のもつ合目的役割であると考えら れる。こうして, 乳児の生理学的, 栄養学的な観点から, 母乳栄食児に近づくように, DHA を強化した調粉が開 発されている。母乳中には DHA だけでなく, n-6 系で あるアラキドン酸も比較的多く含まれている。DHAの 供給源として使用される精製魚油中には EPA が含まれ ている。EPAを多く含む魚油を早産児に与えると, 乳 児の発有が遅延することが Carlson ら”によって報告さ れて以来，EPAは乳児にとって必要ないと考えられる ようになった。こうして，現在調粉に使用される魚油と してイワシのようにDHAよりも EPAの方が多いもの ではなく, DHAの方が多く EPAの少ない魚, 例えば マグロなどが適している。同時にDHAを強化した調粉 で哺育された早産児の赤血球膜リン脂質中の DHA は母 乳栄養児と同等となったが，アラキドン酸は母乳栄養児 よりも下问ったわ。したがって, 調粉中の高度不飽和脂 肪酸として，DHA は乳児にとって必須性は高いが，同 時にアラキドン酸に刘する配虑が発有面を考えたとき必 要であることがいわれている。こうして，最近では DHA 打よびアラキドン酸とのバランスを整え，さらに 乳児にとって多量必要なコレステロールにも配虑した機 能的に母乳化された製品が市販されている。

早産児を出産した母乳中の脂肪酸組成については, 特 に $\mathrm{n}-6, \mathrm{n}-3$ 系の高度不飽和脂肪酸が出産後の日数が短 いものほど成熟児母乳よりも早産児母乳に多く含まれて いることが報告されている゙。早産児の場合は，早産児
にとって不足傾向にある栄養成分が通常よりも若干多め に含まれていることが分かる。

脂質掑取に関して, 第五次改定日本人の栄養所要量で は, 脂肪エネルギ一比率に加えて脂肪酸の望ましい掑取 比率はお打むね飽和脂肪酸：一価不飽和脂肪酸：高度不 飽和脂肪酸 $=1: 1.5: 1$ とされており, また, 妊娠期, 授乳期には胎児および乳児の適正な発有のためDHA を 適量摄取することが望ましいと記述されている。 $\alpha$-リ ノレン酸から生合成される場合に比べて, 食事から直接 DHA を掑取する方が胎児や乳児へ迅速に蓄積され，胎 児や乳児の機能発達の上で重要な役割を果たしうるから である。動物実験の一つでは, 胎仔期から母親の胎盤を 経由してDHA を体内に取り込み, 出生後は母親の乳汁 を介してDHA を摂取して成長，発有した方が，そうで ない場合に比べて, 脳や肝臟中の DHA 含量は高く維持 され, 離乳後のラットにおいて学習能力が高まるなど, 脳の活性化に役立つことが明らかとなっている"》。これ から発表されようとしている第六次改定日本人の栄養所 要量がじのように決定されるか注意しておくべきであろ う。

\section{3 胎児および乳児の脳の発達}

ヒトの脳の発垟は，生命を受けてからすぐ（胎児のう ち）に発達が始まる。奷娠 40 䓢のうち, 出生前 3 力月 ぐらいの間に胎児への栄養分の補給が急激に始まる。こ の時期にDHA 等の栄養分のうちかなりの量が胎児に胎 盤を介して与えられることは, 胎児の脳の正常な発達の 上で重要なことである。脳の急速な発達は, 脳重量の増 加を含めて出生後約 2 年ぐらい続く。

これまでに，n-3 系不飽和脂肪酸欠乏食を与えて継代 飼有した幼若動物（サル）に打いて，血漿DHA レベル の著しい低下や視力低下が起きること，ラットに対する $\mathrm{n}-3$ 系不飽和脂肪酸欠乏食の投与によって網膜反射能の 低下, 明度并別型学習能力における総反応数の增加と正 答率の低下が起きると報告されている" 脂肪酸の代表であるリノ一ル酸を多量に掑取したとき, $\Delta 6$ 不飽和化醅素がリノール酸と $\alpha$-リノレン酸と両方 に競合して働くため $\alpha$-リノレン酸からの代謝が抑制さ れる。逆に， $\alpha$-リノレン酸を相対的に多く掑取したとき， 不飽和化酵素に対する親和性が $\mathrm{n}-3$ 系の方が n-6 系より も強いことから、リノール酸の代謝が抑制される。また， DHA は乳児の脳や網膜中に多く含まれ, これらの発達 の上で重要な役割を果たしている。さらに, 体組織の脂 肪酸組成は, 食事脂質の影響を大きく受けることは分 かっている。したがって, 生体内で不飽和脂肪酸の代謝 が正常に行われ, 乳児の脳や網膜が順調に発達するため

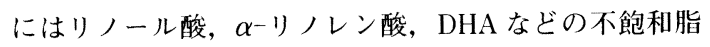
肪酸を食事からバランスよく掑取する必要がある。通常, 
食事から摂取された $\alpha$-リノレン酸から生体内で DHA が合成される。新生児や未熟児にあってはDHA を食事 から揕取しないと, 血漿リン脂質中の DHA レベルが母 乳栄養児のレベルを維持できないことが報告されてい る2。ささらに，食事から撕取した DHA は，食事中の $\alpha-$ リノレン酸から体内合成されたDHAに比べて約 20 倍 の速さで組織中の脂質に取り込まれるといわれてい る3)。

\section{4 成熟児における高度不飽和脂肪酸の意義}

最近，早産児だけでなく，成熟児に対しての高度不飽 和脂肪酸投与の効果に関する研究が報告されるように なってきた。

Agostoni ら ${ }^{10)}$ は， $(n-6+n-3)$ 系高度不飽和脂肪酸, 特にアラキドン酸と DHA，およびコレステロールを加 えた調製乳で哺有した 4 力月齢の成熟乳児では, 発育状 態, 血液脂質パターン，血漿および赤血球の高度不飽和 脂肪酸状態が母乳栄羪児の状態に近くなることを報告し ている。

Kohn $ら^{11)}$ は, 高度不飽和脂肪酸を含む調製乳で哺育 した 1 力月齢の成熟児について調べた結果, 体重発育は 良好であること，不飽和化酵素活性が抑制されているの で高度不飽和脂肪酸を食事から攝取する意義のあること を示している。

Makrides ら ${ }^{(2)}$ は, VEP (Visual evoked potential) 能 による評価から，DHA は，長期的な観点での評価は別 途必要であるものの, 成熟乳児の神経系の最適な発達に とって必須栄養素であるとしている。発有面では母乳栄 養児を含めて試験群の間で差は認められていない。さら にMakrides ら ${ }^{13)}$ は，成熟児にとって DHA が必須であ るか否かをDHAを強化した調製乳で哺有された成熟児 の視力機能により評価し，DHA を母乳レベルまで調粉 に強化すべきことを示した。また，Makridesら(1)は， 魚油と月見草油を強化した調製乳にて哺育した成熟乳児 の赤血球におけるアラキドン酸は，母乳栄養児群やプラ セボ群に比べて低いか, それ以下である一方, DHA レ ベルは母乳栄養児と同等以上であったとしている。この とき, 月見草油の補給は, 魚油との併用において赤血球 中のアラキドン酸レベルを維持することはできなかった と報告している。これらの報告に見られるように, 早産 児ばかりではなく, 成熟児においても高度不飽和脂肪酸 が必要であることを明らかにした報告が多数報告されて きた。

Gibson と Makrides ${ }^{15)}$ は, 新生児栄養における高度不 飽和脂肪酸の役割に関して総説を書いており,その中で, 神経発達における高度不飽和脂肪酸の潜在的意義を明確 にしている。さらにリノール酸からアラキドン酸へ, ま

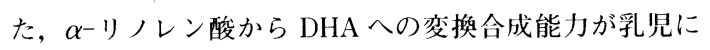

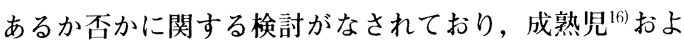
び早産児 ${ }^{17) .18)}$ は高度不飽和脂肪酸を合成できるとしてい る。ただし，合成能力の強さは早産児の方が弱い可能性 は前述の通り, 大いにあり得ることである。この総説中 でこれまで報告された成熟児の神経発達と高度不飽和脂 肪酸との関係の臨床試験をとりまとめて表にしているの でそれを Table 2 に示した。

Birch ら ${ }^{19)} も$ 最近，成熟児をDHA およびアラキドン 酸を含むミルクで哺有したときのVEPの評価から, 脳 および目の最適な発達のためにDHA およびアラキドン 酸が必要であることを報告している。さらに, 高度不飽 和脂肪酸を摂取させた未熟児および成熟児の神経発達に とって高度不飽和脂肪酸は有意義な役割を果たすことを 示している。

Jorgensen $^{20)}$ らは, 生後 4 力月齢の間の母乳栄養成熟 児および人工栄養成熟児における視覚能力と赤血球膜 DHA 状態の研究を行い, DHA を含まないミルクの場合 に比べて, 母乳栄養児の視覚能力の発達が早いことを認 めた。

体内合成された DHA は膜リン脂質に取り込まれる。 体内ではDHA として蓄積されるが, 必要に応じてさら に長い超長鎖脂肪酸に変換されたり, 逆に EPAに戻り, エイコサノイドを産生する。1990 年にBazan ら²1)が体 内の DHAの輸送形態をまとめている。食事中の $\alpha-$ リ ノレンあるいはDHA を搨取すると, 肝蔵の中に取り込

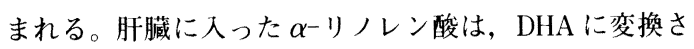
れるか, あるいはDHAの場合は，そのままDHAとし て蓄積される。朋蔵中の DHA は, 脳へ血流によって移 送される。血液脳関門でセレクトされ，DHAは脳関門 を通過して脳に入る。脳に入った DHA は, その中で蓄 積されるか, 網膜ではリサイクルされて利用される。こ の一部は血液に移行し, 脳へ再び入り，もしくは肝臟に 戻った後再び血流にのって脳に移行するという循環を繰 り返す。

一方，吸収されたアラキドン酸も DHA と競合する形 をとりながら膜リン脂質に取り込まれ，プロスタグラン ジン等の酸化生成物を産生し, 生体機能をコントロール する。

筆者ら翼は, 乳児の学習能力状態を確認すべく, 飼料 として,リノール酸を $75 \%$ 含み, $\alpha$-リノレン酸をほと んど含まないサフラワー油を配合した群，一方，リノ一 ル酸を $52 \% ， \alpha$-リノレン酸を $6.5 \%$ 含む大岁油を配合 した 2 種類の飼料を調製した。n-6 系だけを含む場合と， $\mathrm{n}-6$ 系と $\mathrm{n}-3$ 系を比較的バランスよく含む場今の一つの 飼料を雌ラットに与え, ある時期に㚱娠, 出産させて, 食䬣性脂質の違いが胎仔や新生ラットの体内の生理的状 態にどのような影響を及ぼすかを調べた。その結果，付 親の乳を絞ってその組成を分析すると，一般組成はあま 
Table 2 Neurodevelopmental Outcomes of Term Infants in Randomized Clinical Trials of Long Chain Fatty Acid Supplementation ${ }^{15}$.

\begin{tabular}{|c|c|c|c|c|}
\hline Reference & Diet & Test & Age & Results \\
\hline $\begin{array}{l}\text { Makrides, et al., } 1995 \\
(n=55)\end{array}$ & $\begin{array}{l}\text { HM } \\
\text { SF, LA:ALA 17:1.5 } \\
+ \text { FO, EPO }\end{array}$ & T-VEP acuity & $\begin{array}{l}16 \mathrm{wks} \\
30 \mathrm{wks}\end{array}$ & $\begin{array}{l}\mathrm{HM} \& \mathrm{FO}, \mathrm{EPO}>\mathrm{SF} \\
\mathrm{HM} \& \mathrm{FO}, \mathrm{EPO}>\mathrm{SF}\end{array}$ \\
\hline $\begin{array}{l}\text { Agostoni,et al., } 1995 \\
(n=86)\end{array}$ & $\begin{array}{l}\text { HM } \\
\text { SF, LA:ALA 11:0.7 } \\
+ \text { egg PL, EPO }\end{array}$ & DQ & $4 \mathrm{mths}$ & $\mathrm{HM} \&$ egg PL, EPO > SF \\
\hline $\begin{array}{l}\text { Carlson,et al., } 1995 \\
(n=58)\end{array}$ & $\begin{array}{l}\mathrm{HM} \leqq 3 \text { mths } \\
\text { SF, LA:ALA } 22: 2 \\
+ \text { egg PL }\end{array}$ & acuity cards & $\begin{array}{l}2 \mathrm{mths} \\
4,6,9,12 \mathrm{mths}\end{array}$ & $\begin{array}{l}\text { HM \& }+ \text { egg PL }>\text { SF } \\
\text { no difference with diet }\end{array}$ \\
\hline $\begin{array}{l}\text { Auestad,et al., } 1995 \\
(n=120-200)\end{array}$ & $\begin{array}{l}\mathrm{HM} \leqq 3 \text { mths } \\
\text { SF, LA:ALA } 22: 2 \\
+ \text { egg PL } \\
+ \text { TO }\end{array}$ & $\begin{array}{l}\text { S-VEP acuity } \\
\text { acuity cards } \\
\text { Bayley's Test } \\
\text { McArthur CDI }\end{array}$ & $\begin{array}{l}2,4,6,9,12 \mathrm{mths} \\
2,4,6,9,12 \mathrm{mths} \\
12 \mathrm{mths} \\
14 \mathrm{mths}\end{array}$ & $\begin{array}{l}\text { no difference with diet } \\
\text { no difference with diet } \\
\text { no difference with diet } \\
\text {-ve correlation:RBC DHA \& CDI }\end{array}$ \\
\hline $\begin{array}{l}\text { Jorgensen,et al., } 1998 \\
(n=51)\end{array}$ & $\begin{array}{l}\text { HM } \\
\text { SF, LA:ALA } 12.7: 1.2 \\
+ \text { FO } \\
+ \text { FO, BO }\end{array}$ & S-VEP acuity & $4 \mathrm{mths}$ & $\mathrm{HM}>\mathrm{SF}$ \\
\hline$\underset{(n=112)}{\text { Birch,et al., } 1996}$ & $\begin{array}{l}\text { SF, LA:ALA not reported } \\
+ \text { DHA } \\
+ \text { DHA, AA }\end{array}$ & $\begin{array}{l}\text { ERG } \\
\text { S-VEP acuity } \\
\text { acuity cards }\end{array}$ & $\begin{array}{l}6 \mathrm{wks} \\
17 \mathrm{wks} \\
6,17 \mathrm{wks} \\
6,17 \mathrm{kws}\end{array}$ & $\begin{array}{l}+ \text { DHA \& + DHA, AA }>\text { SF } \\
\text { no difference with diet } \\
+ \text { DHA \& + DHA, AA > SF } \\
\text { no difference with diet }\end{array}$ \\
\hline $\begin{array}{l}\text { Clausen,et al., } 1996 \\
(n=97)\end{array}$ & $\begin{array}{l}\text { HM } \\
\text { SF, LA:ALA not reported } \\
\text { + DHA, AA }\end{array}$ & acuity cards & $3 \mathrm{mths}$ & no difference with diet \\
\hline $\begin{array}{l}\text { Gibson,et al., } 1997 \\
(n=91)\end{array}$ & $\begin{array}{l}\text { HM } \\
\text { SF, LA:ALA } \\
+ \text { egg PL } \\
+ \text { TO }\end{array}$ & T-VEP acuity & $\begin{array}{l}4 \mathrm{mths} \\
8 \mathrm{mths}\end{array}$ & $\begin{array}{l}\text { no difference with diet } \\
\mathrm{HM}>\text { all formula }\end{array}$ \\
\hline
\end{tabular}

Abbreviations: HM, human milk; SF, standard formula; LA, linoleic acid; ALA, $\alpha$-linolenic acid; PL, phospholipid; EPO, evening primrose oil; FO, fish oil; TO, tuna oil; BO, borage oil; T-VEP, transient visual evoked potential; S-VEP, sweep visual evoked potential; DQ, developmental quotient; CDI, communicative developmental inventory; wks, weeks; mths, months; RBC, red blood cell; DHA, docosahexaenoic acid; AA, arachidonic acid. When the abbreviations DHA and AA are used, no information regarding the source of these fatty acids was provided.

り変わらないが, 脂肪酸組成の中で, 特にDHAのレベ ルは, サフラワー油の場合 $0.04 \%$ と低くなった。しか し大豆油の場合 $0.18 \%$ と比較的高い数值が得られた。 したがって，母親のラットの乳は，食餌の脂質内容がそ のまま反映されることが分かった。リノール酸も同様の 傾向が見られた。また, 朋臓および脳中のリン脂質, 特 にPEと PCに含まれているアラキドン酸と DHA を見 ると, アラキドン酸はさほど変化しなかったが, 出生直 後の新生仔の DHA は, 肝臓中では大豆油群が $15 \%$ と 非常に高く, サフラワー油群では $2 \%$ 弱であった。また, PCに比べて PEの方がより多くの DHAを含んでいた。 一方, サフラワー油群では, ドコサペンタエン酸 $\left(\mathrm{DPAn}^{-}\right.$ 6）が主体を占めていた。こうして，リノール酸と $\alpha^{-リ}$ ノレン酸を含む大只油抢よびリノール酸を含むサフラ ワー油の間で蔵器の脂肪酸に大きな違いが生じることが 分かった。この食䬦脂質の違いが生体の機能の上で, ど
のような影響を及ぼすかを調べるために，胎仔期から一 定の飼料で有てた生後 6 週歯のラットをプールの中で泳 がす水迷路型遊泳試験を試みた。その結果, 大豆油群の 方がサフラワー油群に比べて到達時間が短く, 学習能力 が良い傾向にあった。統計学的検討を行い, 食慨脂質の 違いに有意差が認められた。第 1 日目から第 2 日目ま で, 遊泳回数打よび日数が増加するにつれ, 到達時間は 低下してきたが，それをまとめた平均值としては，サフ ラワー油群で到達時間が長く, 大豆油群の方が短い結果 が得られた。

この試験では, 大豆油群の方が学習能力が高い傾向を 示した。山本らきも，サフラワー油とシソ油を用いて， 明度弁別型学習能力試験を実施し, DHA の元になる $\alpha^{-}$ リノレン酸を含むシソ油群の方が学習能力の優れている ことを示している。

以上をまとめると, 大豆油㠌取時では, 大量の DHA 
が母親ラットの乳汁中および新生ラットや仔ラットの臓 器中に蓄積され, サフラワー油掑取時では, 大量のアラ キドン酸が母親ラットの乳汁中および新生ラットおよび 仔ラットの臟器中に蓄積された。その効果として, 幼児 期に遊泳試験法にて評価した学習能力は, 大豆油掑取時 の方がサフラワー油摂取時に比べて優れていた。大豆油 を掑取した新生ラットおよび仔ラットの組織りン脂質中 のアラキドン酸レベルに変化はないものの, 多量の DHA が離乳期以降ではなく, 胎仔期からラットの脳に 蓄積されていたことが脳の発達の上で貢献して, 仔ラッ トの脳の機能改善に寄与して, この学習能力の向上に関 係したと考えられる。

続いて, 同様の方法を用いて魚油を配合したときの栄 養生理的意義を検討した。母親から分泌されている乳中 では, 食慨の影響を受けて魚油群が非常に多くの DHA を分泌していることが分かった。17，19，21 日の在胎 日数と出生後 2 週歯と 7 週齢におけるデータを取り, 比 較検討した。魚油群では, 肝臓中のアラキドン酸が低下 していた。胎仔期に特に大きな影響が出て，有意差を認 めた。肝臓中の DHA は, 胎仔期において絶えず魚油非 添加群よりも高いレベルにあった。また, 対照群でも $\alpha$ リリレン酸から合成された DHA のあることが分かっ た。さらに, 特に胎仔期から出生直後は, 合成能力が弱 いといわれている通り，DHAレベルが著しく低下した。 この時期は，母親から栄湌を掑取しなければならず, 新 生仔にとって非常に大きな環境の変化が起きる時であ る。生まれた直後も, 食慨から DHA を掑取する必要が あると考えられた。

脳中の DHA は, 肝臓と同様, 胎仔において魚油群の 方が高い傾向にあったが, 出生後 7 週㱓では魚油非添加

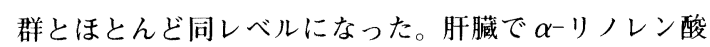
から合成された DHA が脳に運ばれた分も寄与した結果 と考えられた。7週䶔では, 脳中の DHA が飽和状態に なっているのかもしれない。アラキドン酸については, リン脂質中で，特にPI 中に非常に多く含まれていた。 これは食慨による違いが認められない。アラキドン酸の 生体に打ける役割を考えた時，イノシトールリン脂質は 非常に重要な成分であると考えられる。

以上の魚油配合の研究から, 母親ラットの乳汁脂肪酸 組成は食餉性脂質によって大きく影響を受け, 魚油椇取 時の乳汁中の DHA レベルは魚油非掑取時に比べて有意 に高くなることが分かっている。また，魚油掑取時にお ける胎仔扰よび仔ラットの臓器中の DHA レベルは魚油 非椇取時に比べて有意に高い状態であり, 遊泳試験法に よる学習能力では, 魚油椇取時の方が魚油非掑取時に比 べて有意に優れていた。脳の発達が完了する離乳期から ではなく, 脳の発達が始まる胎仔期から DHA を含む魚 油を掑取したことが，脳中の EPAではなく, DHA レ
ベルを大きく高め, 仔ラットの学習能力向上に寄与した と考えられる。

別の実験として，鈴木らは，迷路板を用いた記憶学習 能力試験が行っている23)。イワシ油とパーム油を含有す る飼料を離乳直後から 12 力月間投与し, 24 時間絶水し た後, 迷路の出口に水を置き, 入り口からマウスを入れ, 出口を捜す能力を測定した。その結果，イワシ油を投与 した群の方がパーム油群よりも早く出口に到達すること が分かった。

これらのラットにおけるデータは，臨床的に得られて いるデータを潜在的に裏付けする内容である。今後とも 長期に渡る研究が必要と考えられる。

(受付：1999年 4 月 27 日, 受理：1999年 6 月 24 日)

\section{文献}

1) A. Kanazawa, T. Miyazawa, H. Hirono, M. Hayashi, K. Fujimoto, Lipids, 26, 53 (1991).

2) S.E. Carlson, P.G. Rhodes, U.S. Rao, D.E. Goldger, Pediatr. Res., 21, 507 (1987).

3) FAO/WHO Joint Report : Dietary fats and oils in human nutrition. FAO Technical Papers Series No.3, FAO, Rome, (1987).

4) M. Neuringer, W.E. Conner, C.V. Petten, L. Barstad, J. Clin. Invest., 73, 272 (1978).

5) W.S. Harris, W.E. Conner, S. Lindsey, Am. J. Clin. Nutr., 40, 780 (1984).

6) 米久保明得, 食品と開発, 31, 17 (1996).

7) 大元習子，日本小児科学会雑誌，94，224 (1990).

8) 岡本ふさ子, 小児栄養消化器病学会雑誌，6, 123 (1992).

9) N. Yamamoto, M. Saitoh, A. Moriuchi, M. Nomura, H. Okuyama, J. Lipid Res., 28, 144 (1987).

10) C. Agostoni, E. Riva, R. Bellu, S. Trojan, D. Luotti, M. Giovannini, J. Amer. College Nutr., 13, 658 (1994).

11) G. Kohn, G. Sawatzki, J.P. van Biervliet, Eur. J. Clin. Nutr., 48, Suppl., S 1 (1994).

12) M. Makrides, M.A. Neumann, K. Simmer, J. Pater, R.A. Gibson, Lancet, 345, 1463 (1995).

13) M. Makrides, M.A. Neumann, R.A. Gibson, Lipids, 31, 115 (1996).

14) M. Makrides, M.A. Neumann, K. Smmer, R.A. Gibson, Lipids, 30, 941 (1995).

15) R.A. Gibson, M. Makrides, Acta Paediatr., 87, 1017 (1998).

16) T.U. Sauerwald, D.L. Hachey, C.L. Jensen, H.M. Chen, R.E. Anderson, W.C. Heird, Pediatr. Res., 41, 183 (1997).

17) V.P. Carnielli, D.J.L. Wattimena, I.H.T. Luijendijk, A. Boerlage, H.J. Degenhart, P.J.J. Sauer, 
Pediatr. Res., 18, 61 (1995).

18) H. Demmelmair, U.v. Schenck, E. Behrendt, T. Sauerwald, B. Koletzko, J. Pediatr. Gastroenterol. Nutr., 21,. 31 (1995).

19) E.E. Birch, D.R. Hoffman, R. Uauy, D.G. Birch, C. Prestidge, Pediatr. Res., 44, 20 (1998).

20) M.H. Jorgensen, O. Hernell, P. Lund, G. Holmer, K.F. Michaelsen, Lipids, 31, 99 (1996).

21) N.G. Bazan, Nutrition and the Brain, vol.8, edited by R.J. Wurtman, J.J. Wurtman, Raven Press, New York, p.11 (1990).

22) A. Yonekubo, S. Honda, M. Okano, K. Takahashi, Y. Yamamoto, Biosci. Biotech. Biochem., 58, 799 (1994).

23) H. Suzuki, S.J. Park, M. Tamura, S. Ando, Mechanism of Ageing and Development, 101, 119 (1998). 


\section{[総説 $]$}

\section{魚油の健康機能}

鈴木 平光

林水産省食品総合研究所

（テ 305-8642 茨城県つくば市観音台 2-1-2）

魚油には，ドコサヘキサエン酸（DHA）やエイコサペンタエン酸（EPA）といった $\mathrm{n}-3$ 系多価不飽和脂肪酸が 豊富に含まれている。これらの脂肪酸は, 心血管系疾患, がん, 炎症の予防に有効であるため, 生物学的に重要 な脂質として広く認められている。さらに, 魚油, 特にDHA, の摂取は, 脳の発達, 記憶学習能, 視覚機能に 影響するということが多くの研究で明らかにされている。最近では, 痴呆症や精神障害に及ほすす DHA 油の予防 及び治療効果が報告されている。この総説では, 魚油の健康機能についてまとめると同時に, 高齢者の知能や視 力に及ほす DHA 油の効果についてのデー夕も紹介する。

(連絡者：鈴木平光) Vol.48, No.10, 1017 (1999)

\title{
[総説］母乳および調製粉乳と乳児の脂質栄養
}

\author{
米 久保 明 得
}

明治乳業株式会社栄養科学研究所

（广 189-8530 東京都東村山市栄町 1-21-3）

\section{母乳㧍よび調製粉乳と乳児の脂質栄養}

母乳は乳児の発育と発達にとって最善の栄養法である。しかし，母乳が十分分泌されない場合や社会的および 医学的に母乳を与えられない場合などには，母乳栄養が必ずしも可能ではない。このような場合には母乳に変わ りうる唯一の食品が調製粉乳である。母乳中にはリノール酸, アラキドン酸, $\alpha$-リノレン酸, DHA などの高 度不飽和脂肪酸が十分含まれている。DHA などの脂肪酸バランスが日本人母乳並に整った調製粉乳が現在開発 されている。成熟児における高度不飽和脂肪酸の意義が視覚能力などの評価により，ラットで得られた DHAの 効果を支持する内容が得られつつある。

（連絡者：米久保明得） Vol.48, No.10, 1025 (1999)

\section{[総説 $]$}

\section{老化脳と脂質栄養}

\author{
安藤 進 \\ 東京都老人総合研究所生体膜部門

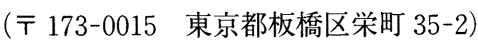

老化に伴うニューロン機能の低下は，シナプス伝達障害に由来すると考えられる。脳としての機能低下は記憶 障害で明らかにされ，その根底にあるメカニズムとしてシナプス伝達障害が証明されている。シナプス機能低下 は, 脂質との関わりではシナプス膜の加齢による脂質組成と物理化学的性質の変化によって説明される。コレス テロール/リン脂質 (C/P) 比と細胞膜内の脂質非対称性分布が, 膜の受容体機能とそれにつづくシグナル伝達 機構の制御に重要な役割を果たしていると考えられる。

脂質栄養学の視点から, 食物脂質のシナプス機能と, ひいては神経機能への効果を議論し, 特に攝取脂質の量 と質に焦点があてられる。脂質の質については, 飽和酸, 多価不飽和酸, とりわけ $\mathrm{n}-6$ と $\mathrm{n}-3$ 系列の生理的効果 が考察される。それら効果の分子機構も提示されている。最後に，アルツハイマー病やパーキンソン病などの病 理に対して複合脂質を用いる薬理学的アプローチについても触れる。

（連絡者：安藤 進） Vol.48, No.10, 1033 (1999) 